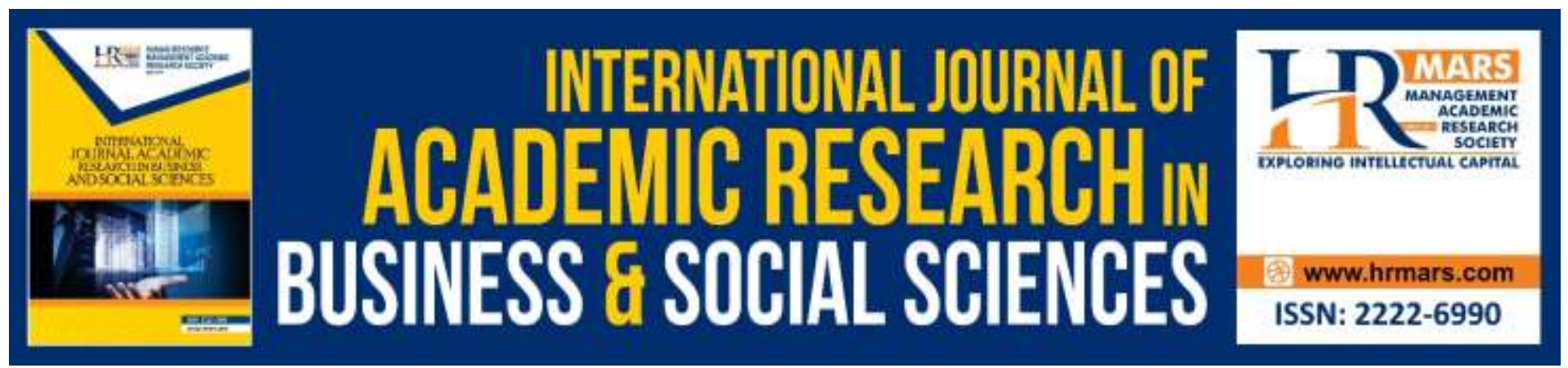

\title{
The Impact of Internal Audit and its Quality on Sales in Economic Institutions: A Case Study (Al-Ahlia Cement Company - Libya)
}

\begin{abstract}
Marwan Ibrahim Alfadhli, Nik Mohd Norfadzilah bin Nik Mohd Rashid Madam Noryati Yaakub
\end{abstract}

To Link this Article: http://dx.doi.org/10.6007/IJARBSS/v8-i8/4434

DOI: $10.6007 /$ IJARBSS/v8-i8/4434

Received: 11 July 2018, Revised: 28 July 2018, Accepted: 29 July 2018

Published Online: 18 August 2018

In-Text Citation: (Alfadhli, Rashid, \& Yaakub, 2018)

To Cite this Article: Alfadhli, M. I., Rashid, N. M. N. bin N. M., \& Yaakub, M. N. (2018). The Impact of Internal Audit and its Quality on Sales in Economic Institutions: A Case Study (Al-Ahlia Cement Company - Libya). International Journal of Academic Research in Business and Social Sciences, 8(8), 50-65.

Copyright: (C) 2018 The Author(s)

Published by Human Resource Management Academic Research Society (www.hrmars.com)

This article is published under the Creative Commons Attribution (CC BY 4.0) license. Anyone may reproduce, distribute, translate and create derivative works of this article (for both commercial and non-commercial purposes), subject to full attribution to the original publication and authors. The full terms of this license may be seen at: http://creativecommons.org/licences/by/4.0/legalcode

Vol. 8, No. 8, August 2018, Pg. $50-65$

Full Terms \& Conditions of access and use can be found at http://hrmars.com/index.php/pages/detail/publication-ethics 


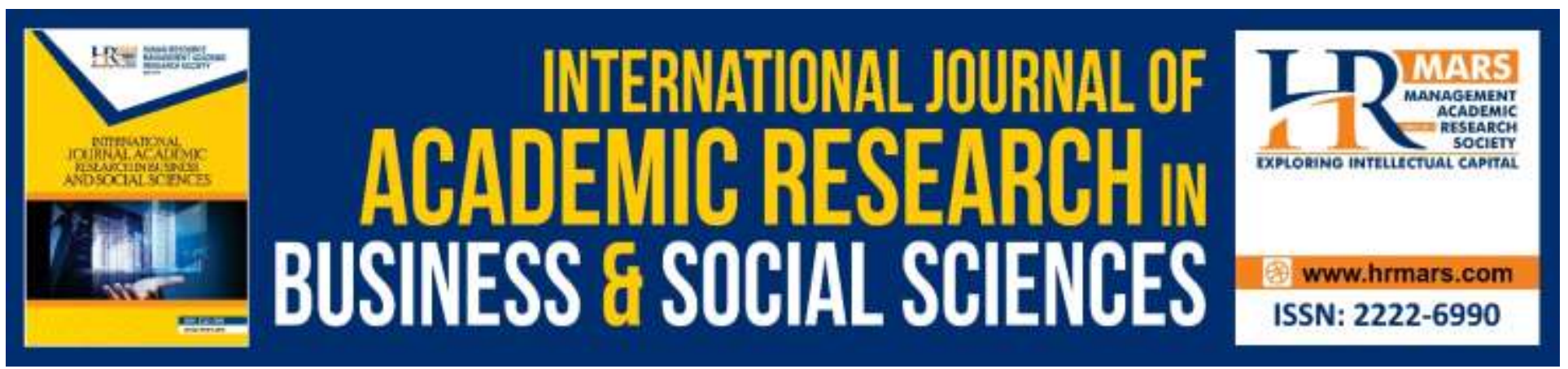

\title{
The Impact of Internal Audit and its Quality on Sales in Economic Institutions: A Case Study (Al-Ahlia Cement Company - Libya)
}

\author{
Marwan Ibrahim Alfadhli \\ Master of Accounting - Faculty of Economics and Management, University Sultan Zainal Abidin \\ (UniSZA) \\ Email: Marwanalfadhli1988@gmail.com
}

Dr. Nik Mohd Norfadzilah bin Nik Mohd Rashid

Head of Accounting Department at the Faculty of Economics and Management (UniSZA)

\author{
Dr. Madam Noryati Yaakub
}

Lecturer at the Faculty of Economics and Management (UniSZA)

\begin{abstract}
The objective of this study was to find out the effect of internal audit and its quality on sales in the economic institutions, because the auditing works to show the actual result of the institution. The research was based on the statistical analysis program (SPSS) and descriptive analysis. The researchers used the arithmetic mean the standard deviation to describe the questionnaire items and Pearson correlation coefficient between variables. The study found that there is a strong relationship between the internal audit and the quality of internal audit, and sales in economic institutions, and that the staff of the audit department are characterized by integrity and honesty. The internal audit has a prominent role in the decision-making by the beneficiaries, and the presence of a special section of the audit of sales in the institution checks the invoices with the goods out, and monitors the sales by an independent person. The researcher recommended that the opinions of the auditors should be according to the accepted accounting principles. The courses should be done in dealing with the computer in completing the transactions. He recommended that the sales operations should be analyzed periodically to avoid fraud in the invoices.
\end{abstract}

Keywords: Internal Audit, Sales, Economic Institutions.

\section{Introduction}

The audit profession has been known since the man began to practice activities to satisfy his own needs and others (Yora, 2015). The importance of auditing and its role in the performance of institutions has become apparent recently, as it has evolved from its basic role of auditing records 
and data (Momani \& Shweiyat, 2007), and give the opinion about it, to protect the assets of the institutes, and the optimal use of resources and predict in future with the possibility of continuing to work in order to achieve the objectives of the institution and to ensure the integrity and validity of the accounting data, and it is known that the performance of the organizations is measured through the results achieved, and the extent of their ability to achieve their objectives.

The emergence of the industrial revolution has accompanied the continuous development of the economic institutions and its size, transactions were increased. It were turned from small institutes with simple transactions to large institutes (Mazon, 2013), which led to widen the gap between the administration and other departments, thus the administration was forced to know the efficiency and validity of the data and information, in addition to know the outcome of the activity.

Since the institute deals with several different parties with interests directly or indirectly in the institute, all these parties need to know the outcome of the activity because it reflects the real level of the institute and decision-making by users (Fakhr \& Shala, 2016), and that the administration is responsible for responding to the recommendations that presented by the owners, and they may charge them if they fail to achieve the goals or reward them for their efforts to serve the benefit of the company (EI Najjar, 2012). Accordingly, the administration seeks to ensure that its financial statements have the correct characteristics and true information in order to take the decision by users of these lists to meet the needs of the customers to get actual data.

\section{The Problem of the Study}

The problem of the study shows that Libya is considered a country undergoing financial corruption due to the recent events in the country, such as the coming out of the state in 2011, the destruction of institutions, lack of supervision and the large number of financial corruption. And financial corruption is considered one of the biggest problems facing the Libyan economy at present, and it is an obstacle to social and economic development (Massoud \& Sassi, 2016), Financial and managerial corruption has now spread in most state institutions due to the absence and weakness of Control and legal institutions (Almalty, 2016).

The auditing is currently going through a period of corruption and the auditor may be a party to these corruption operations. He may have a lot of default in the exercise of his functions (Al-Futtaisi, 2014), because he is not subject to any supervision of the authorities, resulting in a large number of embezzlement, fraud and manipulation, especially in the public money, and this leads to a lack of efficiency of the institution and low economic status and reputation. Moreover, corruption is not the main concern of this study, but the quality and efficiency of the auditing when it comes to dealing with problems that arise as a result of the lack of experience in auditing the accounts of this institution.

\section{Study Questions}

This study raises the fundamental question of the efficiency of the internal audit on sales in economic institutions (study of the National Cement Company / Libya). Several questions emerge from this question:

- Is there a statistically significant effect of internal audit on sales in the institution?

- Is there a statistically significant effect of quality of internal audit (professional ability, objectivity, independence, credibility, honesty, integrity, confidentiality) and on sales in the institution? 
INTERNATIONAL JOURNAL OF ACADEMIC RESEARCH IN BUSINESS AND SOCIAL SCIENCES

Vol. 8, No. 8, August 2018, E-ISSN: 2222-6990 C 2018 HRMARS

\section{The Hypotheses of the Study}

The hypotheses of the study depending on the problem of the study itself, as it presented possible answers to the phenomenon studied, and expected solutions to the problem of study, and was based on the following hypotheses:

- There is no statistically significant effect of internal audit on sales in the institution.

- There is no statistically significant effect of quality of internal audit (professional ability, objectivity, independence, credibility, honesty, integrity, confidentiality) on sales in the institution.

\section{The Objectives of the Study}

- To examine if there is a statistical effect of internal audit on sales in the institution.

- To examine whether there is a statistically significant effect of quality of internal audit (professional ability, objectivity, independence, credibility, honesty, integrity, confidentiality) on sales in the institution.

\section{The Importance of the Study}

The importance of the study lies in the fact that it sheds light on a subject of great importance, namely that the audit works to show the actual result of the institution. The main goal of any organization is to make a profit and stay (Derball, 2012). The amount and volume of sales is the main factor of any industry to achieve maximum profit. The more sales are properly supervised, the greater the profit for the organization. The organization requests the reconciliation of accounting data in light of the development of accounting, also the needs of the customer to review the growth of the institution sales and its stature, because the sales function is one of the basic functions on which the economic institution depends (Hafsia \& Rabeeha, 2015).

\section{Scientific Importance}

The importance of the study is shown the researcher referred to the internal audit in particular because it is important in institutions, and there is a lack of studies on internal audit on sales, and that the previous studies did not talk about the internal audit on sales in Widely, but included the internal audit and its impact on both (Quality of financial statements, risk management, performance appraisal, profit forecasting).

And also the importance of research show Is that it included the role of internal audit on sales in an environment that has passed and is still going through periods of financial corruption as a result of what happened in the country of problems and the exit of the state and it is apparently talking about Libya, but in essence includes all countries that have passed and are still going through the same periods of corruption, Because of the wars that have occurred and are still happening such as Egypt, Tunisia, Sudan, Yemen, Syria, Iraq, All these cities are now undergoing periods of great financial corruption as a result of the wars and the absence of the organs of power and control. (Elsayed, 2016), (Mohammed \& Abbas, 2016). 
INTERNATIONAL JOURNAL OF ACADEMIC RESEARCH IN BUSINESS AND SOCIAL SCIENCES Vol. 8, No. 8, August 2018, E-ISSN: 2222-6990 @ 2018 HRMARS

\section{The Variables of the Study}

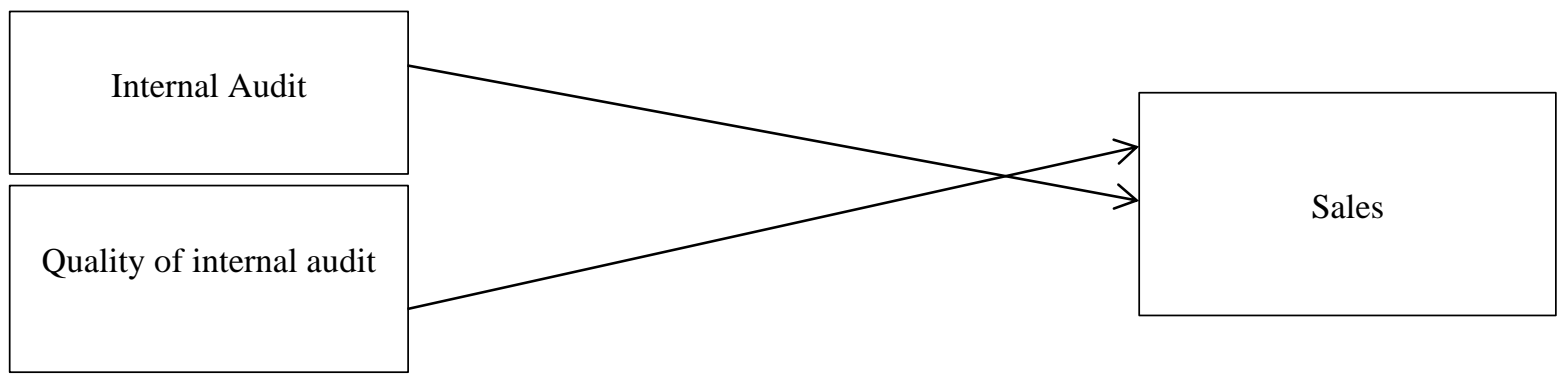

\section{Methodology of the Study}

The researchers relied on the program of statistical analysis (SPSS) because it corresponds with the current study, and it is possible to access all the detailed information concerning the problem of study. Statistical descriptive method, such as arithmetic mean and standard deviation, was used. Reference has been made to the studies, journals and documented books, and proven their credibility and analysis in order to reach the goals set. A questionnaire was distributed in order to collect data and preliminary information in order to obtain the best picture of the subject of the study.

\section{Community and Sample of Study}

The study community included two important departments in each of Al Ahlia Cement Company's factories: Audit and Sales. The number of the two sections of the 117 employees as follows:

\begin{tabular}{|c|c|}
\hline The Department & The Number \\
\hline The Internal Audit & 37 \\
\hline The Sales Department & 80 \\
\hline Total & $\mathbf{1 1 7}$ \\
\hline
\end{tabular}

The researchers relied on the table of (Krejcie \& Morgan, 1970) in order to choose the sample number for the collection of data, where the sample of the Internal Audit Department was 36 people, where the Sales Department was 66 people, and was fully recovered.

\section{Methods of Collecting Information}

First: Data of the Theoretical Side.

In order to obtain this data, many previous studies, and published books and periodicals have been reviewed, as well as follow-up of some conferences that are concerned with financial auditing in general and the topic under study "Internal Audit and its impact on sales in economic institutions" in particular. Through the study, the methods and sound and scientific foundations in the writing of studies were identified, and follow all what is new in the field of study.

\section{Second: The Questionnaire}

A questionnaire was distributed to identify and study some of the vocabulary related to the study, collect and compile the necessary data, then unload and analyze it using the statistical analysis program (SPSS), and use statistical descriptive method such as arithmetic mean and standard deviation, as well as Pearson Coefficient and doing the suitable tests to reach to the significant statistical indicators supporting the subject of the study. 
INTERNATIONAL JOURNAL OF ACADEMIC RESEARCH IN BUSINESS AND SOCIAL SCIENCES Vol. 8, No. 8, August 2018, E-ISSN: 2222-6990 @ 2018 HRMARS

\section{Sincerity of the Questionnaire}

The researcher formulated the questionnaire according to the previous studies that discussed the same topic, and it was presented to the experienced in this field and those interested in the field of scientific research and the work of the necessary observations until it reached its final form.

\section{Stability of the Questionnaire}

To make sure that the questionnaire is understandable and clear, and its soundness and credibility, the researchers conducted an experiment and test the questionnaire questions, and know the interrelationship of the scales. The evaluation was done by counting Cronbach's alpha coefficient, because it indicates to the coherence and correlation between all the paragraphs,

Because the Cronbach's alpha coefficient gives estimation of stability, and according to (George \& Mallery, 2003), the Cronbach's alpha rules are as follows:

\begin{tabular}{|c|c|}
\hline Percent & The Grade. \\
\hline .9 & Excellent \\
\hline .8 & Good \\
\hline .7 & Fair \\
\hline .6 & Week \\
\hline .5 & Very Week \\
\hline
\end{tabular}

The questionnaire is designed according to the quintile measurement of (Likert Scale), which is a scale that likely to have five answers to the paragraphs of the questionnaire, so that the researcher can determine the views of each paragraph of the questionnaire by the study members. The researchers coded the entries as follows:

\begin{tabular}{|c|c|c|c|c|c|}
\hline Extent of effect & Very big & Big & Medium & Small & Very small \\
\hline Degree & 5 & 4 & 3 & 2 & 1 \\
\hline
\end{tabular}

The source: Ezz, Abdel Fattah. Introduction to descriptive inductive statistics using (SPSS), part 111. P.540.

\begin{tabular}{|c|c|c|c|c|c|}
\hline Mean arithmetic & $4.5-5$ & $3.75-4.5$ & $3-3.75$ & $2-3$ & Less than 2 \\
\hline $\begin{array}{c}\text { Relative } \\
\text { importance }\end{array}$ & Very high & High & Medium & Low & Very low \\
\hline
\end{tabular}

Prepared by the researcher depending on previous studies.

In order to verify the validity of the questionnaire for this test, the researchers applied the $\alpha$ Cronbach equation on the scores of the sample members, and as mentioned by (Isaac \& Michael, 1995), the number of samples between 10 and 30 are useful. The experiment was calculated as follows:

\begin{tabular}{|c|c|c|}
\hline The Department & $\begin{array}{c}\text { Cronbach's } \\
\text { alpha }\end{array}$ & Number of Questionnaire \\
\hline Quality of internal audit & .877 & 10 \\
\hline The internal audit & .908 & 10 \\
\hline Sales & .879 & 13 \\
\hline Total & .888 & 33 \\
\hline
\end{tabular}


INTERNATIONAL JOURNAL OF ACADEMIC RESEARCH IN BUSINESS AND SOCIAL SCIENCES

Vol. 8, No. 8, August 2018, E-ISSN: 2222-6990 C 2018 HRMARS

The results show that the stability coefficient Of Cronbach's alpha terms of the internal audit amounted to (.908) which is excellent, while the internal audit quality amounted (.877), which is a ratio more than good, while the Cronbach's alpha terms of sales questionnaire was (.879) and it was above good.

Thus, it is clear that the Cronbach's alpha coefficient for the total items of the questionnaire for both sections reached (.888) which is more than good ratio, which indicated that there being consistency between the paragraphs of the questionnaire. Therefore, it is possible to rely on the results of the questionnaire, its stability and its credibility and its ability to reach and achieve the goals of the study.

\section{The Personal Information}

The researchers will analyze the personal data of the sample subjects in Internal Audit and Sales Departments, by gender, age, academic qualification, scientific specialization, job title and number of years of experience in the field of profession, as in the following tables and forms:

First: Gender data

\begin{tabular}{|c|c|c|c|c|}
\hline \multirow{2}{*}{ Gender } & \multicolumn{2}{|c|}{ Internal Audit Department } & \multicolumn{2}{c|}{ Sales Department } \\
\cline { 2 - 5 } & Number & Percent & Number & Percent \\
\hline Male & 24 & 66.7 & 41 & 62.1 \\
\hline Female & 12 & 33.3 & 25 & 37.9 \\
\hline Total & $\mathbf{3 6}$ & $\mathbf{1 0 0 . 0}$ & $\mathbf{6 6}$ & $\mathbf{1 0 0 . 0}$ \\
\hline
\end{tabular}

Second: The age data

\begin{tabular}{|c|c|c|c|c|}
\hline The Age & \multicolumn{2}{|c|}{ Internal Audit Department } & \multicolumn{2}{c|}{ Sales Department } \\
\cline { 2 - 5 } & Number & Ratio & Number & Ratio \\
\hline $\begin{array}{c}\text { From } 20 \text { to } \\
\text { less than } 30\end{array}$ & 7 & 19.4 & 21 & 31.8 \\
\hline $\begin{array}{c}\text { From } 30 \text { to } \\
\text { less than } 40\end{array}$ & 20 & 55.6 & 31 & 47.0 \\
\hline $\begin{array}{c}\text { From } 40 \text { to } \\
\text { less than 50 }\end{array}$ & 8 & 22.2 & 9 & 13.6 \\
\hline $\begin{array}{c}\text { From } 50 \text { and } \\
\text { more }\end{array}$ & 1 & 2.8 & 5 & 7.6 \\
\hline Total & $\mathbf{3 6}$ & $\mathbf{1 0 0 . 0}$ & $\mathbf{6 6}$ & $\mathbf{1 0 0 . 0}$ \\
\hline
\end{tabular}

Third: Data on scientific qualification

\begin{tabular}{|c|c|c|c|c|}
\hline \multirow{2}{*}{ Scientific Qualification } & \multicolumn{2}{|c|}{ Internal Audit Department } & \multicolumn{2}{c|}{ Sales Department } \\
\cline { 2 - 5 } & Number & Ratio & Number & Ratio \\
\hline General Secondary & 2 & 5.6 & 10 & 15.2 \\
\hline Bachelor degree & 23 & 63.9 & 46 & 69.7 \\
\hline Master degree & 10 & 27.8 & 8 & 12.1 \\
\hline PhD & 1 & 2.8 & 2 & 3.0 \\
\hline Total & $\mathbf{3 6}$ & $\mathbf{1 0 0 . 0}$ & $\mathbf{6 6}$ & $\mathbf{1 0 0}$ \\
\hline
\end{tabular}


INTERNATIONAL JOURNAL OF ACADEMIC RESEARCH IN BUSINESS AND SOCIAL SCIENCES Vol. 8, No. 8, August 2018, E-ISSN: 2222-6990 @ 2018 HRMARS

Forth: The data on scientific specialization

\begin{tabular}{|c|c|c|c|c|}
\hline \multirow{2}{*}{$\begin{array}{c}\text { Scientific } \\
\text { Specialization }\end{array}$} & \multicolumn{2}{|c|}{ Internal Audit Department } & \multicolumn{2}{c|}{ The Sales Department } \\
\cline { 2 - 5 } & The number & The ratio & The number & The ratio \\
\hline Accounting & 30 & 83.3 & 23 & 34.8 \\
\hline Financing banks & 0 & 0 & 5 & 7.6 \\
\hline Administration & 1 & 2.8 & 17 & 25.8 \\
\hline Economics & 2 & 5.6 & 9 & 13.6 \\
\hline Other & 3 & 8.3 & 12 & 18.2 \\
\hline Total & $\mathbf{3 6}$ & $\mathbf{1 0 0 . 0}$ & $\mathbf{6 6}$ & $\mathbf{1 0 0 . 0}$ \\
\hline
\end{tabular}

Fifth: Data on the job title

\begin{tabular}{|c|c|c|c|c|}
\hline \multirow{2}{*}{ Job title } & \multicolumn{2}{|c|}{ Internal Audi Department } & \multicolumn{2}{c|}{ Sales Department } \\
\cline { 2 - 5 } & Number & Ratio & Number & Ratio \\
\hline $\begin{array}{c}\text { Head of the } \\
\text { department }\end{array}$ & 0 & 0 & 2 & 3.0 \\
\hline Accountant & 13 & 36.1 & 20 & 30.3 \\
\hline Auditor & 17 & 47.2 & 3 & 4.5 \\
\hline Others & 6 & 16.7 & 41 & 62.1 \\
\hline Total & $\mathbf{3 6}$ & $\mathbf{1 0 0 . 0}$ & $\mathbf{6 6}$ & $\mathbf{1 0 0 . 0}$ \\
\hline
\end{tabular}

Sixth: Data on the period of experience

\begin{tabular}{|c|c|c|c|c|}
\hline \multirow{2}{*}{ The period } & \multicolumn{2}{|c|}{ Internal Audit Department } & \multicolumn{2}{c|}{ Sales Department } \\
\cline { 2 - 5 } & Number & Ratio & Number & Ratio \\
\hline Less than 5 years & 16 & 44.4 & 34 & 51.5 \\
\hline From 5 to 10 years & 12 & 33.3 & 24 & 36.4 \\
\hline From 11 to 15 years & 4 & 11.1 & 4 & 6.1 \\
\hline More than 15 tears & 4 & 11.1 & 4 & 6.1 \\
\hline The total & $\mathbf{3 6}$ & $\mathbf{1 0 0 . 0}$ & $\mathbf{6 6}$ & $\mathbf{1 0 0 . 0}$ \\
\hline
\end{tabular}

Analysis of the Questionnaire Items

Analysis of the items on the Internal Audit:

\begin{tabular}{|c|c|c|c|c|c|}
\hline \multirow[b]{2}{*}{ The items of internal audit } & \multirow[b]{2}{*}{$\begin{array}{l}\text { Arithmet } \\
\text { ic mean }\end{array}$} & \multirow[b]{2}{*}{$\begin{array}{l}\text { Standard } \\
\text { deviation }\end{array}$} & \multicolumn{3}{|c|}{ (\%) The total } \\
\hline & & & $\begin{array}{c}\text { Big, } \\
\text { very } \\
\text { big }\end{array}$ & $\begin{array}{c}\text { Little, } \\
\text { very } \\
\text { little }\end{array}$ & Mean \\
\hline $\begin{array}{c}\text { Internal audit provides curate and } \\
\text { sound information to the decision } \\
\text { makers who can find solutions } \\
\text { and alternatives }\end{array}$ & 4.69 & 0.467 & 100 & 0 & 0 \\
\hline $\begin{array}{l}\text { Internal audit is an essential } \\
\text { reference for information on how } \\
\text { to implement decisions and to be } \\
\text { accurate and realistic during the } \\
\text { implementation process }\end{array}$ & 4.39 & 0.549 & 97.2 & 0 & 2.8 \\
\hline
\end{tabular}


INTERNATIONAL JOURNAL OF ACADEMIC RESEARCH IN BUSINESS AND SOCIAL SCIENCES Vol. 8, No. 8, August 2018, E-ISSN: 2222-6990 @ 2018 HRMARS

\begin{tabular}{|c|c|c|c|c|c|}
\hline $\begin{array}{l}\text { Internal audit is an auxiliary tool } \\
\text { or advisory body to be taken by } \\
\text { the management when making } \\
\text { high quality decisions }\end{array}$ & 4.47 & 0.774 & 88.9 & 2.8 & 8.3 \\
\hline $\begin{array}{l}\text { Internal audit helps in providing } \\
\text { the suitable atmosphere to take } \\
\text { good and effective decisions. }\end{array}$ & 4.00 & 0.756 & 72.2 & 0 & 27.8 \\
\hline $\begin{array}{l}\text { Internal audit helps the } \\
\text { management of the institution to } \\
\text { implement its policies and } \\
\text { procedures and achieve effective } \\
\text { and efficient goals }\end{array}$ & 3.58 & 1.228 & 52.8 & 19.5 & 27.8 \\
\hline $\begin{array}{l}\text { Internal audit contributes to } \\
\text { detect weakness and identifying } \\
\text { weaknesses and strengths in the } \\
\text { institution. }\end{array}$ & 2.78 & 1.222 & 22.2 & 44.5 & 33.3 \\
\hline $\begin{array}{l}\text { The internal audit makes checking } \\
\text { processes and provides the } \\
\text { advices to the institution about } \\
\text { the reviewed processes. }\end{array}$ & 2.83 & 1.502 & 41.6 & 55.5 & 2.8 \\
\hline $\begin{array}{c}\text { The internal auditor submits } \\
\text { periodic reports to senior } \\
\text { management }\end{array}$ & 2.86 & 1.417 & 33.4 & 38.9 & 27.8 \\
\hline $\begin{array}{l}\text { The internal auditor has special } \\
\text { skills in dealing with individuals } \\
\text { and communicating effectively. }\end{array}$ & 2.75 & 1.461 & 38.9 & 50.0 & 11.1 \\
\hline $\begin{array}{c}\text { Senior management relies on the } \\
\text { internal audit reports in there } \\
\text { decisions }\end{array}$ & 2.97 & 1.320 & 36.1 & 33.3 & 30.6 \\
\hline Total & 3.53 & 1.0696 & 58.33 & 24.45 & 17.23 \\
\hline
\end{tabular}


INTERNATIONAL JOURNAL OF ACADEMIC RESEARCH IN BUSINESS AND SOCIAL SCIENCES Vol. 8, No. 8, August 2018, E-ISSN: 2222-6990 @ 2018 HRMARS

Analysis of the Questionnaire Items of the Internal Audit Quality:

\begin{tabular}{|c|c|c|c|c|c|}
\hline \multirow{2}{*}{$\begin{array}{l}\text { The internal audit quality } \\
\text { items }\end{array}$} & \multirow{2}{*}{$\begin{array}{l}\text { Arithm } \\
\text { etic } \\
\text { mean }\end{array}$} & \multirow{2}{*}{$\begin{array}{l}\text { Standard } \\
\text { deviation }\end{array}$} & \multicolumn{3}{|c|}{ (\%) The total } \\
\hline & & & $\begin{array}{l}\text { Big, very } \\
\text { big }\end{array}$ & $\begin{array}{c}\text { Little, } \\
\text { very little }\end{array}$ & $\begin{array}{l}\text { The } \\
\text { mean }\end{array}$ \\
\hline $\begin{array}{l}\text { Existence of internal and } \\
\text { external courses to develop } \\
\text { the capabilities of the auditor }\end{array}$ & 4.53 & 0.560 & 97.3 & 0 & 2.8 \\
\hline $\begin{array}{c}\text { Availability of the appropriate } \\
\text { scientific qualification to the } \\
\text { auditor to perform the audit } \\
\text { works }\end{array}$ & 4.47 & 0.609 & 94.5 & 0 & 5.6 \\
\hline $\begin{array}{l}\text { The auditor has the } \\
\text { appropriate professional } \\
\text { experience to perform the } \\
\text { audit works }\end{array}$ & 4.03 & 0.736 & 75.0 & 0 & 25.0 \\
\hline $\begin{array}{l}\text { The auditor should respect the } \\
\text { confidentiality of the } \\
\text { information that he gets } \\
\text { during doing his work. }\end{array}$ & 3.81 & 1.037 & 66.7 & 11.1 & 22.2 \\
\hline $\begin{array}{l}\text { The justice of the auditor in } \\
\text { providing information to } \\
\text { stakeholders so as to insure } \\
\text { the continuity of the company } \\
\text { and not liquidate it. }\end{array}$ & 3.64 & 1.018 & 55.5 & 11.1 & 33.3 \\
\hline $\begin{array}{c}\text { The auditor ability to minimize } \\
\text { the risk of errors in the } \\
\text { financial statements }\end{array}$ & 2.53 & 1.298 & 25.0 & 61.1 & 13.9 \\
\hline $\begin{array}{l}\text { The auditor ability to follow } \\
\text { the accounting principles set in } \\
\text { the form of criteria based on } \\
\text { the accounting application }\end{array}$ & 2.81 & 1.618 & 41.6 & 50.0 & 8.3 \\
\hline $\begin{array}{l}\text { The rules, behavior and ethics } \\
\text { of profession contribute to } \\
\text { improve the quality of audit } \\
\text { performance. }\end{array}$ & 2.61 & 1.479 & 25.0 & 52.8 & 22.2 \\
\hline $\begin{array}{l}\text { The auditor's credibility in the } \\
\text { information contained in the } \\
\text { financial lists that meet the } \\
\text { needs of its users. }\end{array}$ & 2.36 & 1.073 & 13.9 & 55.6 & 30.6 \\
\hline $\begin{array}{l}\text { The auditor is characterized by } \\
\text { honesty, integrity and bias in } \\
\text { favor of the institution. }\end{array}$ & 4.00 & 1.042 & 77.8 & 11.1 & 11.1 \\
\hline Total & 3.48 & 1.047 & 57.23 & 25.28 & 17.5 \\
\hline
\end{tabular}


INTERNATIONAL JOURNAL OF ACADEMIC RESEARCH IN BUSINESS AND SOCIAL SCIENCES

Vol. 8, No. 8, August 2018, E-ISSN: 2222-6990 (C) 2018 HRMARS

Analysis of the Items on the Sales Department

\begin{tabular}{|c|c|c|c|c|c|}
\hline \multirow[b]{2}{*}{ The items of sales department } & \multirow[b]{2}{*}{$\begin{array}{l}\text { Arithme } \\
\text { tic } \\
\text { mean }\end{array}$} & \multirow[b]{2}{*}{$\begin{array}{l}\text { Standard } \\
\text { deviations }\end{array}$} & \multicolumn{3}{|c|}{ (\%) The total } \\
\hline & & & $\begin{array}{l}\text { Big, } \\
\text { very } \\
\text { big }\end{array}$ & $\begin{array}{l}\text { Little, very } \\
\text { little }\end{array}$ & $\begin{array}{l}\text { The } \\
\text { mean }\end{array}$ \\
\hline $\begin{array}{c}\text { Check the orders of the } \\
\text { customers and agree on it before } \\
\text { send them by the sales } \\
\text { department }\end{array}$ & 4.15 & 0.68483 & 68.4 & 1.5 & 12.1 \\
\hline $\begin{array}{c}\text { Control of outgoing quantities by } \\
\text { an independent person }\end{array}$ & 4.36 & 0.59837 & 93.9 & 0 & 6.1 \\
\hline $\begin{array}{l}\text { The biling department is } \\
\text { independent of each department } \\
\text { in the institution. }\end{array}$ & 4.42 & 0.58337 & 95.5 & 0 & 4.5 \\
\hline $\begin{array}{l}\text { The function is separated: sales, } \\
\text { shipping, financial, accounting }\end{array}$ & 3.94 & 0.83902 & 62.1 & 0 & 37.9 \\
\hline $\begin{array}{c}\text { The sales applications which were } \\
\text { not completed should reviewed } \\
\text { periodically }\end{array}$ & 3.44 & 1.06884 & 37.8 & 16.7 & 45.5 \\
\hline $\begin{array}{l}\text { Comparing the shipping } \\
\text { documents with the invoices to } \\
\text { assure that the goods which were } \\
\text { shipped has invoices }\end{array}$ & 2.36 & 1.22332 & 18.2 & 65.2 & 16.7 \\
\hline $\begin{array}{l}\text { Register all the sales invoices in } \\
\text { details in the selling diary. }\end{array}$ & 1.76 & 0.87812 & 4.5 & 84.9 & 10.6 \\
\hline $\begin{array}{c}\text { Keeping a copy of the invoices } \\
\text { file, and analyze the sales } \\
\text { regularly }\end{array}$ & 1.83 & 1.01653 & 9.1 & 78.8 & 12.1 \\
\hline $\begin{array}{c}\text { Sales analysis is conducted on a } \\
\text { regular basis. }\end{array}$ & 3.00 & 1.28901 & 39.4 & 33.4 & 27.3 \\
\hline $\begin{array}{c}\text { Comparing the invoices and } \\
\text { accounting registration of the } \\
\text { sales }\end{array}$ & 3.53 & 0.86326 & 50.0 & 10.6 & 39.4 \\
\hline The total & 3.28 & 0.904467 & 47.89 & 29.11 & 21.22 \\
\hline
\end{tabular}


INTERNATIONAL JOURNAL OF ACADEMIC RESEARCH IN BUSINESS AND SOCIAL SCIENCES

Vol. 8, No. 8, August 2018, E-ISSN: 2222-6990 @ 2018 HRMARS

\section{Analysis of Hypothesis Results}

\section{Pearson Correlation}

- There is no statistically significant difference between the internal audit and sales in the institution.

\begin{tabular}{|c|c|c|c|}
\hline & & Internal audit & The sales \\
\hline \multirow{3}{*}{ Internal audit } & Pearson Correlation & 1 & $.859^{* *}$ \\
\cline { 2 - 4 } & Sig (2-tailed) & & .001 \\
\cline { 2 - 4 } & The number & 10 & 10 \\
\hline \multirow{2}{*}{ The sales } & Pearson Correlation & $.859^{* *}$ & 1 \\
\cline { 2 - 4 } & Sig(2-tailed) & .001 & 10 \\
\cline { 2 - 4 } & The number & 10 & \\
\hline
\end{tabular}

**Correlation is significant at the 0.01 level (2-tailed)

The table shows the relationship between the internal audit and the sales, and illustrates that the significance level is 0.01 and the correlation is 0.859 . This indicates that there is a strong linear correlation and relationship between the internal audit and sales in the institution. This negates the validity of the third hypothesis and shows a strong relationship between the two variables.

- There is no statistically significant relationship between the quality of internal audit and sales in the institution.

\begin{tabular}{|c|c|c|c|}
\hline \multirow{3}{*}{ Internal audit quality } & $\begin{array}{c}\text { Internal audit } \\
\text { quality }\end{array}$ & The sales \\
\cline { 2 - 4 } & Pearson Correlation & 1 & $.863^{* *}$ \\
\cline { 2 - 4 } & Sig (2-tailed) & & .001 \\
\hline \multirow{2}{*}{ The sales } & The number & 10 & 10 \\
\cline { 2 - 4 } & Pearson Correlation & $.863^{* *}$ & 1 \\
\cline { 2 - 4 } & Sig (2-tailed) & .001 & 10 \\
\cline { 2 - 4 }
\end{tabular}

**Correlation is significant at the 0.01 level (2-tailed)

According to the previous table which shows the relationship between the quality of internal audit and sales in the institution. Note that the significance level is 0.01 and the correlation coefficient is 0.863. This indicates that there is a strong linear correlation between the quality of the internal audit and sales in the institution. This negates the validity of the second hypothesis and shows that there is a relationship between the two variables.

\section{Multiple Regression Analysis}

Multiple Regression Analysis

\begin{tabular}{|c|c|c|c|}
\hline Dependent variables & Coefficients & Prob & Multicollinearity \\
\hline Internal Audit & $0.224^{*}$ & 0.000 & 2.512 \\
\hline quality of internal audit & $0.670^{*}$ & 0.000 & 2.505 \\
\hline C & $9.791^{*}$ & 0.000 & \\
\hline
\end{tabular}

Notes: ${ }^{*}$, Denotes rejection of the null hypothesis at $1 \%$ significance level. 
The table indicates the coefficient of regression of the dependent and independent variables. The coefficient of regression for internal audit is $\beta$ 0.224. It indicates that as the efficiency of internal audit increases, the sales increases. The coefficient of regression for internal audit quality is $\beta 0.670$. It indicates that as the quality of audit (professional ability, objectivity, independence, credibility, honesty, integrity, \& confidentiality) increases, the amount of sales increases as well.

Based on the analysis of the impact of internal audit on sales in Al-Ahlia Cement Company - Libya, the internal audit has a significant impact on the volume of sales in the company. According to these findings, internal audit is one of the main components that result in significant increase in sales in the institution. Therefore, the internal audit department is important in the institution. Because its business depends on sales as a source of revenue to survive, the institution should consider the importance of internal audit. This is because according to the findings of this study, internal audit contributes significantly to the success of the institution.

\section{Test Hypotheses}

- There is no statistically significant relationship between the internal audit and sales in the institution. It has been found that the internal audit has and an import role in the institution and in conducting the work and help the administration to reach its goals, and that there is a strong statistically significant correlation between the internal audit and sales in the institution.

- There is no statistically significant relationship between the quality of audit and sales in the institution. It has been found that there is consensus among staff members in the internal audit department that the quality of the audit is important in the management of the institution's work and that there is a significant relationship between the quality of Internal audit and sales in the institution and this relationship is very strong in the institution.

\section{Study Results}

- Most of the internal auditors of the company has the ethics of the profession, and there are policies for recruitment and compliance with it.

- Some auditors do not have sufficient skill in using computer systems, and there is no audit by the auditors on the consistency of the system of the institution with the policies established. The department manager does not review the work done by the auditors, while the head of the department should know the level of the professional performance of the auditors in the department.

- The company conducts courses for auditors to develop their abilities periodically, and that the auditors have the appropriate qualifications and professional experience to carry out the tasks assigned to them, and they do their work with complete confidentiality in respect of the information obtained.

- Auditors do not have enough ability to reduce errors in the financial statements, and the majority of auditors have the ability to adhere to the accounting principles established.

- Internal auditors are characterized by honesty and integrity and are biased towards the benefit of the institution.

- Internal Audit contributes to the decision-making by the beneficiaries through the information provided by the Internal Audit Department, as well as using the internal audit as a basic reference to the information on how to implement the decisions and also the accuracy of the implementation process. The internal audit assists the management in making strategic 
decisions, and contributes in making decisions of quality and effectiveness to achieve the objectives set, by providing the appropriate atmosphere. The auditing also helps the management of the institution to implement its policies for the purpose of achieving its goals efficiently and effectively.

- There is a special department for auditing the sales in the institution and its functions are auditing invoices and customer requests and, also control the goods received and out of the stores, and also matching the goods out of the stores with existing invoices.

- The sales department examines the customer orders and its approval by the sales department. There is also an independent person who checks and monitors outgoing quantities, and the billing department is independent of the rest of the company's departments.

- Internal audit effectively contributes to increasing sales in the institution by controlling all the things related with sales through checking customers' requests and comparing actual sales recorded in books with invoices issued.

\section{Recommendations}

- The institution must perform sessions and courses to the auditors continuously so that they can know the computer systems and to be able to form their views according to the accepted accounting principles. The staff of the audit department should also review the institution's own system in order to comply with the established policies. The internal audit manager should review the work of the staff of the audit department.

- The need for justice in providing information to stakeholders and to ensure the continuation of the institution, and there must be certain policies to measure the integrity and independence of auditors.

- The need to focus on the audit of financial statements to avoid the risk of errors, and to raise awareness among auditors for the need to follow the accounting principles when carrying out the work entrusted to them.

- The need to know the weaknesses in the institution and reporting and advise management of all the reviewed operations, and the auditor's periodic report to management, and to raise awareness among employees in the audit department on how to deal with individuals and how to contact them, and the need for senior management to respond to the advice provided by the auditor in the form of reports to reach the goals set.

- The sales department must review all the orders received by the department and has not been disbursed, and must make sure that all orders that have been shipped have invoices or not.

- Sales staff must register all sales invoices in a sales diary, and keep a copy of this invoices.

- The need for the audit department to have accountants to analyze the sales on a regular basis, and record the goods sold first by first in the diaries, and the knowledge of their knowledge and application of the common principles of accounting, and must perform courses especially for accountants in the sales department for registration in the diaries to prepare the financial statements.

- The need to focus in universities on the principles and responsibilities of accounting, because they are the basis and the pivot on which the accountants and auditors are depending. As well as to show the importance of auditing and the role of the auditor in the institutions and its contribution to achieve its set goals. 
INTERNATIONAL JOURNAL OF ACADEMIC RESEARCH IN BUSINESS AND SOCIAL SCIENCES

Vol. 8, No. 8, August 2018, E-ISSN: 2222-6990 @ 2018 HRMARS

- There should be some research that talks about internal auditing and its relationship with purchases, and researches belong to auditing the items of the financial statements for its importance in continuation of the institution.

\section{References}

Abu Gabriel, A. Y. (2015). The impact of internal audit on the management of profits in industrial companies listed on the Amman Stock Exchange. Master Thesis, Zarqa University: Jordan.

Abu Watfa, H. S. (2009). The role of internal audit in improving the efficiency and effectiveness of financial investments. "Applied Study on Companies Listed on the Palestine Securities Exchange". Master Thesis. Islamic University. Gaza.

Al Malty, A. F. (2016). Analytical study of the causes and effects of administrative and financial corruption in the Libyan economy. Libyan Affairs, (3), 58-71.

Al-Afifi, M. M. (2009). The extent of the internal auditor's ability to apply the standards of professional performance of the internal audit of the international financial institutions to address the phenomenon of financial corruption in the economic institutions (applied study on public shareholding companies operating in the Gaza Strip), Master Thesis, Islamic University, Gaza

Al-Futtaisi, A. A. (2014). The financial crisis and the deficiencies in the control of public money in Libya - Analytical study of the reports of the Audit Bureau for the years 2008-2012. University Journal. Vol. 1, No. 16.

Derball, S. (2012). The behavior of economic institutions in financing their internal growth - A comparative study between the small, medium and large Algerian institutions during the period from 2006 to 2010. University of Qassidi Merabah. Ouargla: Algeria.

El-Najjar, A. K. M. (2012). El Najjar, Abdel Karim Mohamed. (2012). The role of auditors in verifying the qualitative characteristics of accounting information in financial statements. - Applied research in a sample of Iraqi companies listed in the Iraqi Stock Exchange. Baghdad University.

Elsayed, D. T. (2016). Causes of Corruption in the Arab Spring Countries: A Cross-National Comparative Perspective. Paper presented at the 24th World Congress of Political Science Poznan, Poland.

Fakhr, N., \& Shala, M. (2016). The importance of the auditor's acquisition of specialized knowledge in enhancing the credibility of financial reports. Tishreen University Journal of Research and Scientific Studies - Series of Economic and Legal Sciences. Vol. 37, No.3.

George, D., \& Mallery, P. (2003) SPSS for windows step by step: A sample Guide \& reference Boston; Allyn \& Bacon.

Hafisa, I., \& Rabeeha, B. K. (2015). Accounting audit on sales in an economic institution - Case study of Poultry Slaughter Company in Albuwaira Master Thesis. University of Akli Ulhaj. Algeria.

Isaac, S., \& Michael, W. B. (1995). Handbook in research and evaluation. Educational and Industrial Training Services. San Diego.

Issa, S. M. (2008). Specific factors for the quality of the internal audit function in improving the quality of corporate governance - with an applied study. Journal of the Faculty of Commerce for Scientific Research. Volume. 45. Issue 1.

Krejcie, R. V., \& Morgan, D. W. (1970). Determining sample size for research activities. Educational and Psychological Measurement. Vol. 30. pp 607-610.

Massoud, Y. Y., \& Sassi, S. O. (2016). The impact of corruption and instability on the growth of the Libyan economy Applied Study for the period 1996 - 2016. Libyan Affairs, (3), 27-45. 
INTERNATIONAL JOURNAL OF ACADEMIC RESEARCH IN BUSINESS AND SOCIAL SCIENCES

Vol. 8, No. 8, August 2018, E-ISSN: 2222-6990 C 2018 HRMARS

Mazon, M. A. (2011). Accounting Audit from an International Perspective and possibility of its Applicability in Algeria. Algeria University. Algeria.

Momani, M., \& Shweiyat, Z. (2007). The auditor's ability to detect indicators of doubt about the continuity of customers. Al Manara Journal. Vol. 14. Issue 1.

Mubarak, R. I. (no, date). Quality and role of internal audit activities in reducing profit management practices. Applied study on the Saudi environment. King Saud University.

Sari, Y., \& Nugroho, G. W. (2017). Pengaruh Audit Internal Terhadap Operasi Penjualan (Studi Kasus pada PT. Selamat Lestari Mandiri). Jurnal IImiah Ilmu Ekonomi (Jurnal Akuntansi, Pajak dan Manajemen), 5 (10), 94-108.

Shaaban, L. (2013). Internal audit and its role in improving the operation of the institution with the study of the case of "Gas Export Section of the Sonatrak Complex (Sales - Receipts). Algeria University. Algeria.

Wahyuningsih, N., Halim, A., \& Wulandari, R. (2016). PERANAN AUDIT OPERASIONAL DALAM MENUNJANG EFEKTIVITAS PENJUALAN (Studi empiris pada Perusahaan Daerah Air Minum Kabupaten Malang). Jurnal Riset Mahasiswa Akuntansi, 4 (1).

Yora, J. W. C. (2015). Accounting audit in public institutions - Comparative study. University of Boubaker Belqaid. Tlemcen. Algeria.

Zahra, S. (2014). Internal Audit in the Economic Institution, (sales - customers). Case Study Nafthal Foundation GPL Bouira, Master Thesis, University of Akli Mohand Oulhaj, Algeria. 